\title{
Development of small scale screw extrusion machine for production of sawdust briquettes in rural area in Indonesia
}

\author{
Anak Agung Putu Susastriawan, Bambang Wahyu Sidharta \\ Department of Mechanical Engineering, Institute of Science \& Technology AKPRIND, Jl. Kalisahak 28 Yogyakarta, Indonesia
}

Email address:

a_agungs@yahoo.com (A. A. P. Susastriawan)

\section{To cite this article:}

Anak Agung Putu Susastriawan, Bambang Wahyu Sidharta. Development of Small Scale Screw Extrusion Machine for Production of Sawdust Briquettes in Rural Area in Indonesia. International Journal of Energy and Power Engineering. Vol. 3, No. 5, 2014, pp. $250-253$.

doi: 10.11648/j.ijepe.20140305.15

\begin{abstract}
Small scale screw extrusion machine is designed and tested for making compact sawdust briquettes in rural area in Indonesia. The extrusion machine is powered by 5,5 HP gasoline internal combustion engine. In this work, briquetting machine is used to produce sawdust briquettes which two different ratios of starch-sawdust. The ratios of starch to sawdust are 1:4 and 2:4. Sawdust briquettes have a length of $3 \mathrm{~cm}$ and $4 \mathrm{~cm}$ for both composition ratios. The performance of the machine is investigated in term of density changes of briquettes after three days. The density of sawdust briquettes just after extrusion process is compared with the density of sawdust briquettes after 3 days sunlight drying. The result shows that the extrusion machine is able to produce compact sawdust briquettes with different ratios of starch to sawdust. The result also indicates that $3 \mathrm{~cm}$ long sawdust briquettes which starch to sawdust ratio $2: 4$ has the lowest density changes and has the highest compressive strength.
\end{abstract}

Keywords: Briquettes, Sawdust, Extrusion, Density

\section{Introduction}

The demand of fuel wood is still high, mainly for cooking purpose in rural area in Indonesia. The demand of biomass energy in rural area in Indonesia is about equivalent with 225 million barrel crude oil [1].

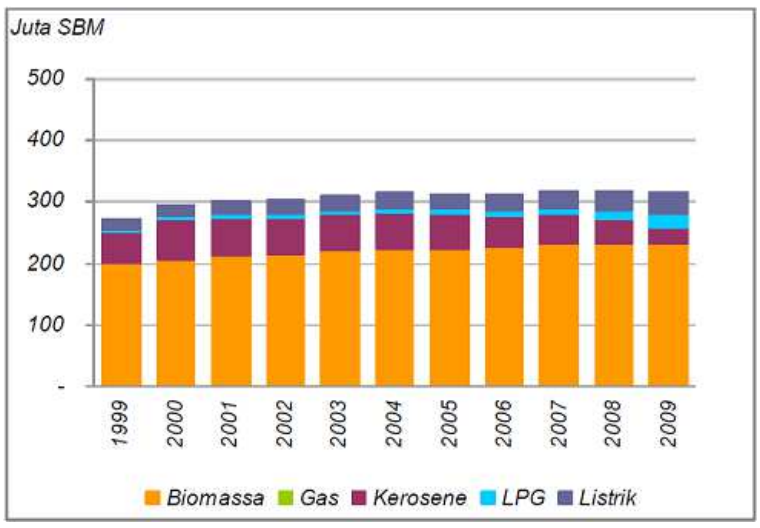

Figure 1. Demand of biomass fuel in Indonesia

Many efforts have been made for supplying the demands, including development of biomass briquettes technology. Briquetting of biomass has been found as a viable technology for upgrading biomass materials, including agricultural residues, particularly in developing countries which abundant biomass waste resources [2]. Various biomass wastes have been utilized for biomass briquettes. Many works on development of biomass briquettes have been done from various types of biomass wastes, such as rise husk [3], and paper pulp [4].

Characteristic of biomass briquettes is affected by many factors, such as briquette's size, moisture content and compacting pressure. Compacting pressure affects the size and shape of biomass briquettes [2]. There is a maximum die pressure for given die size and storage condition beyond which no significant bonding effect can be achieved. Mechanical properties of biomass briquettes can be increased with addition of different type of biomass [4]. Addition of sawdust and paper mill in the mixture can improve compressive strength of biomass briquettes.

Biomass briquettes can be utilized as feed stock of gasifier. Singh et al.[5] produced different length coconut shells briquettes with modification pressing machine. The briquettes have a length of 90,60 , and $35 \mathrm{~mm}$. The $35 \mathrm{~mm}$ briquette is the best characteristic for feedstock of gasifier.

Indonesia has biomass energy potential approximately 46 $\mathrm{GW}$, but only $0,3 \mathrm{GW}$ has been utilized, including sawdust 
biomass from wood processing home industry. Sawdust has been used for making biomass briquettes by pressing machine. The machine generally has high production capacity and needs trained worker. These limit the application of the pressing machine technology in rural area. In this research, small scale extrusion machine is fabricated and tested to produce biomass briquettes from mixture of starch and sawdust. The extrusion machine is designed with small gasoline internal combustion engine which easy to operate. The extrusion briquetting machine is proposed for rural area which abundant source of sawdust in Indonesia.

\begin{tabular}{|l|c|c|c|}
\hline \multicolumn{1}{|c|}{$\begin{array}{c}\text { ENERGI } \\
\text { NON FOSIL }\end{array}$} & SUMBER DAYA & SETARA & $\begin{array}{c}\text { KAPASITAS } \\
\text { TERPASANG }\end{array}$ \\
\hline Tenaga Air & 845.00 juta BOE & $75.67 \mathrm{GW}$ & $4.2 \mathrm{GW}$ \\
\hline Panas Bumi & $219 \mathrm{Juta} \mathrm{BOE}$ & $27.00 \mathrm{GW}$ & $0.8 \mathrm{GW}$ \\
\hline MiniMicro Hydro & $0.45 \mathrm{GW}$ & $0.45 \mathrm{GW}$ & $0.206 \mathrm{GW}$ \\
\hline Biomass & $49.81 \mathrm{GW}$ & $49.81 \mathrm{GW}$ & $0.3 \mathrm{GW}$ \\
\hline Tenaga Surya & - & $4.80 \mathrm{kWh} / \mathrm{m}^{2} / \mathrm{han}$ & $0.01 \mathrm{GW}$ \\
\hline Tenaga Angin & $9.29 \mathrm{GW}$ & $9.29 \mathrm{GW}$ & $0.0006 \mathrm{GW}$ \\
\hline Uranium (Nukir) & $\begin{array}{c}24.112 \text { ton' e. } 3 \text { GW untuk } \\
11 \text { tahun }\end{array}$ & & \\
\hline
\end{tabular}

Figure 2. Biomass energy potential in Indonesia[6]

\section{Experimental Work}

In this work, small screw extrusion machine is designed and manufactured prior to sawdust briquetting process. The main components of extrusion machine are 5,5 HP gasoline internal combustion engine, screw extruder, gear box, transmission system, and machine frame. Figure 3 and Figure 4 show the screw and the die of the extrusion briquetting machine.

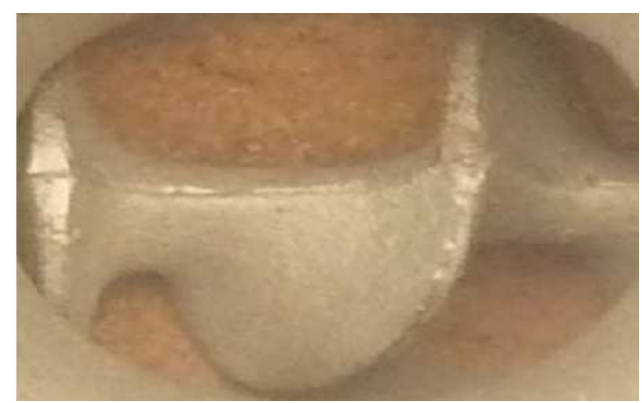

Figure 3. Srew extruder

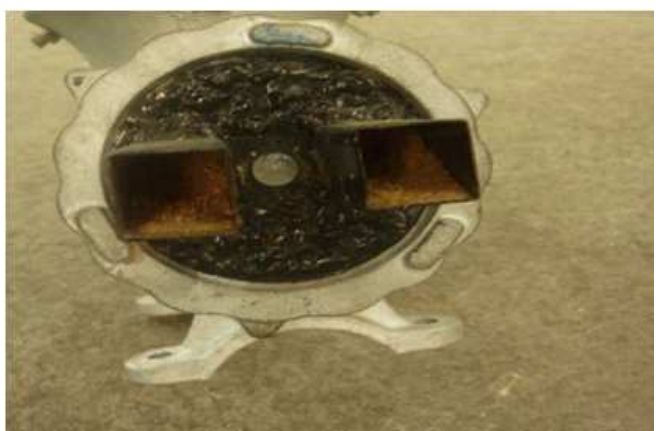

Figure 4. Dies.

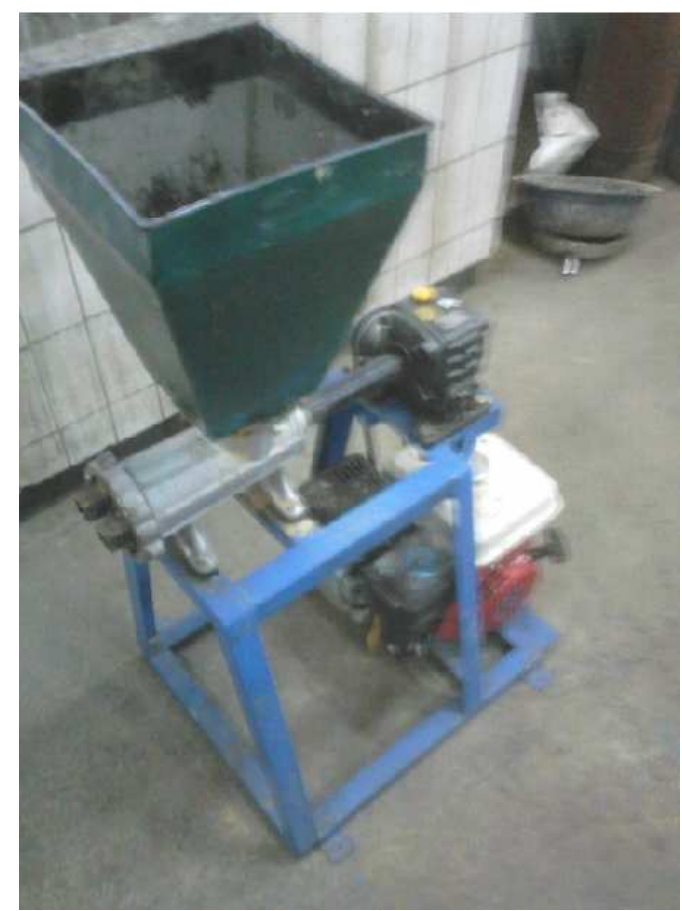

Figure 5. Small scale briquetting machine.

Briquettes are produced from a mixture of sawdust and starch as a bonding material. The mixtures have two different ratios of starch to sawdust, $1: 4$ and $2: 4$. The sawdust briquettes are produced in $3 \mathrm{~cm}$ length and $4 \mathrm{~cm}$ length for each composition ratio.

In this work, the density of briquettes for each length and composition is investigated before drying and after 3 days drying. The result is then compared to obtained density change after 3 days drying. The compressive strength of briquettes is also tested after 3 days sunlight drying. The measurement of compressive strength is conducted in Laboratory of Material Technology, IST. AKPRIND Yogyakarta.

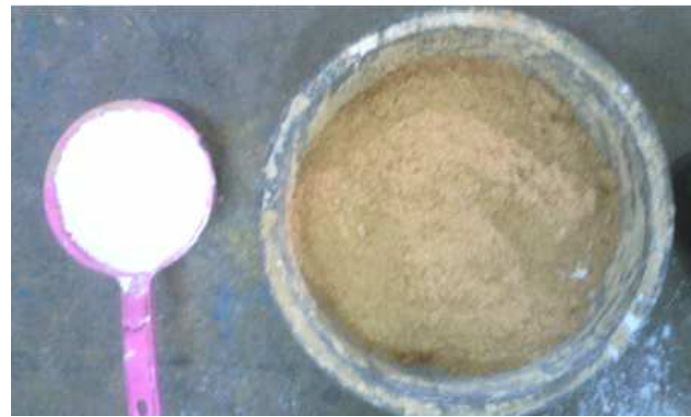

Figure 6. Starch and sawdust.

Density of briquettes is obtained by measuring the weight and volume of briquettes, and can be expressed as

$$
\rho_{b}=\frac{m_{b}}{V_{b}}
$$

where $m_{b}$ is a weight of briquette and $V_{b}$ is a volume of briquette.

Meanwhile, percentage of density change is calculated with 


$$
\Delta \rho=\frac{\rho_{b, w e t}-\rho_{b, d r y}}{\rho_{b, d r y}} x 100 \%
$$

where $\rho_{\mathrm{b} \text {,wet }}$ is density after drying and $\rho_{\mathrm{b} \text {,dry }}$ is density of briquette after 3 days sunlight drying.

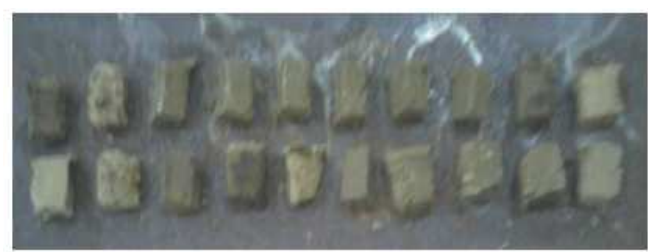

(a) Length of $3 \mathrm{~cm}$

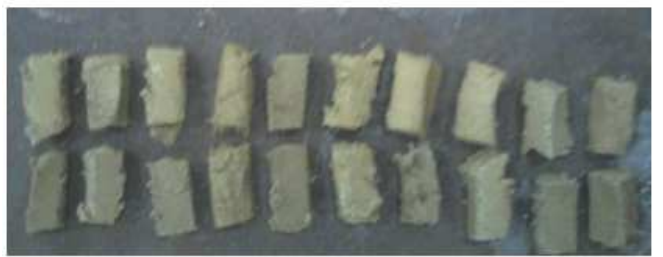

(b) length of $4 \mathrm{~cm}$

Figure 7. Sawdust briquettes.

\section{Results and Discussions}

Figure 8 and Figure 9 show an average density of sawdust briquettes before drying and after 3 days sunlight drying. Sawdust briquettes which $1: 4$ composition ratio of starch to sawdust has higher average density than briquettes which composition ratio of $2: 4$ for both briquette length. This is because more sawdust composition in briquettes of $1: 4$ ratio. Briquettes which composition ratio $1: 4$ and length of $4 \mathrm{~cm}$ has the highest density in order of magnitude $2.118 \mathrm{gr} / \mathrm{cm}^{3}$. In contrast, briquette which composition ratio $2: 4$ and length of $3 \mathrm{~cm}$ has the lowest density in order of magnitude 0.864 $\mathrm{gr} / \mathrm{cm}^{3}$.

\section{Average density just after extrusion}

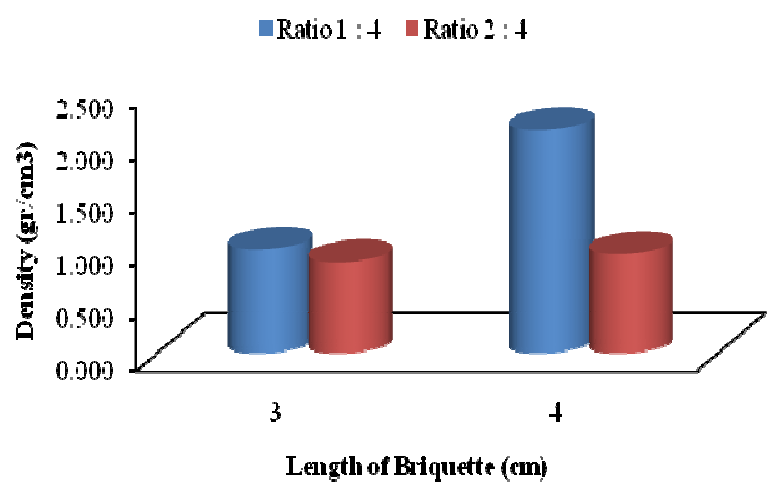

Figure 8. Average density just after extrusion

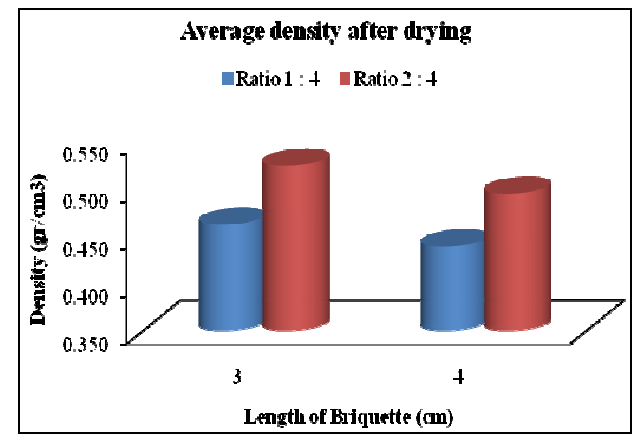

Figure 9. Average density after 3 days drying

After 3 days drying, briquettes which ratio $1: 4$ and length of $3 \mathrm{~cm}$ has the highest density about $0.524 \mathrm{gr} / \mathrm{cm}^{3}$. Meanwhile, the lowest density is $0.439 \mathrm{gr} / \mathrm{cm}^{3}$ for briquettes which composition ratio $1: 4$ and length of $4 \mathrm{~cm}$.

Reduction in density of briquettes after 3 days drying is shown in Figure 10. Briquettes which mixture ratio $2: 4$ and 3 $\mathrm{cm}$ length experience the lowest density reduction, in contrast with briquettes which mixture ratio $1: 4$ and $4 \mathrm{~cm}$ length.

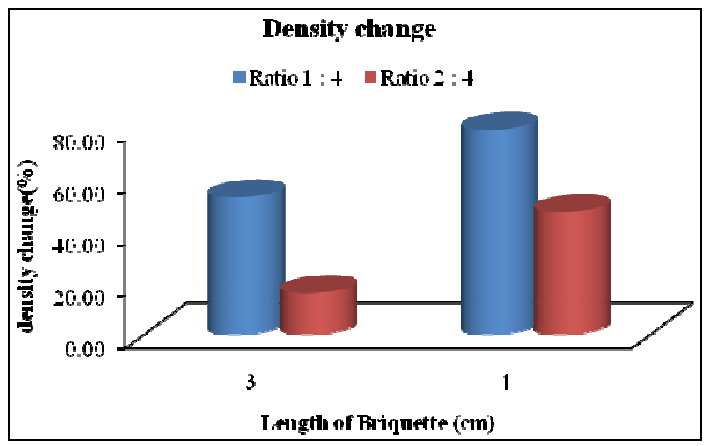

Figure 10. Density change after 3 days drying

Figure 11 shows an average compressive strength of briquettes for both mixture composition ratios. Briquettes which composition ratio of $2: 4$ and length of $3 \mathrm{~cm}$ has the highest compressive strength in order of $0.088 \mathrm{~kg} / \mathrm{mm}^{2}$.

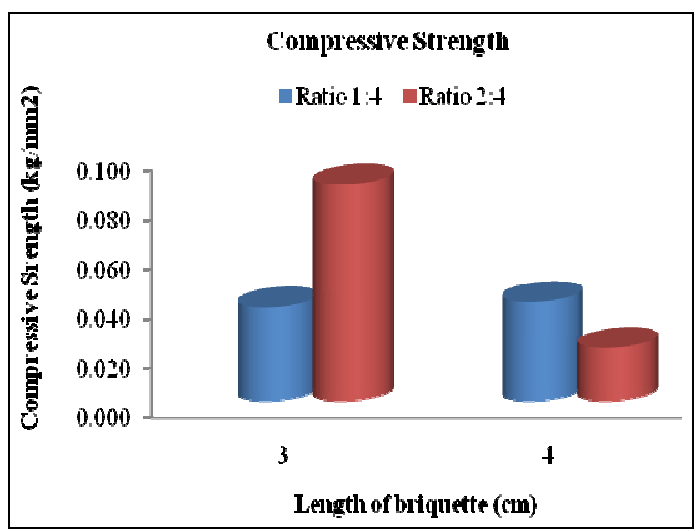

Figure 11. Briquette's compressive strength. 


\section{Conclusions}

It can be concluded that the screw extrusion machine is easily operated for producing sawdust briquettes. The briquettes which composition ratio $2: 4$ of starch to sawdust and length of $3 \mathrm{~cm}$ has optimum mechanical properties in term of density change and compressive strength. The minimum density change is $16.08 \%$ and maximum compressive strength is $0.088 \mathrm{~kg} / \mathrm{mm}^{2}$.

\section{Acknowledgements}

The authors are grateful to the DIKTI- Indonesian Ministry of Education and Culture for providing the financial assistance through the scheme of Hibah Dosen Pemula 2014 which reference number DIPA/023.04.1.673453/2014

\section{References}

[1] ESDM, "Indonesia Energi Outlook 2010", Pusdatin Kementrian Energi dan Sumber Daya Mineral, 2010

[2] C.K.W. Ndiema, P.N. Manga, C.R. Ruttoh, "Influnce of Die Pressure on Relaxation Characteristics of Briquetted Biomass", Energy Conversion and Management, 43 (2002) 2157-2161

[3] Daud Patabang, "Karakteristik Termal Briket Arang Sekam Padi dengan Variasi Bahan Perekat", Jurnal Mekanikal, Vol 3, No 2, 2012

[4] S.Yaman, M. Sahan M., H. Haykiri-Acma, K. Sesen, S. Kucukbayrak, "Fuel Briquettes from Biomass-Lignite Blends, Fuel Processing Technology, 72 (2001) 1-8

[5] R.N. Singh, P.R. Bhoi, S.R. Patel, "Modification of Commercial Briquetting Machine to Produce $35 \mathrm{~mm}$ Diameter Briquettes Suitable for Combustion and Combustion", Renewable Energy 32 (2007) 474-479

[6] ESDM, "Blueprint Pengelolaan Energi Nasional 2005-2025, Kementrian Energi dan Sumber Daya Mineral, 2006 